\title{
Animated Videos Prove to be Beneficial in Teaching English Grammar as EFL: A Neurological Study of How Students Learn and Retain English Grammar
}

\author{
Ibrahem Bani Abdo, Abdel-Hameed Al-Awabdeh \\ Faculty of Foreign Languages, English Language and Literature, University of Jordan, Amman, Jordan \\ Email: ibrahim_re@yahoo.com,drhamedluna79@gmail.com
}

How to cite this paper: Abdo, I. B., \& Al-Awabdeh, A.-H. (2017). Animated Videos Prove to be Beneficial in Teaching English Grammar as EFL: A Neurological Study of How Students Learn and Retain English Grammar. Creative Education, 8, 1415-1423.

https://doi.org/10.4236/ce.2017.89099

Received: November 10, 2016

Accepted: January 8, 2017

Published: July 27, 2017

Copyright $\odot 2017$ by authors and Scientific Research Publishing Inc. This work is licensed under the Creative Commons Attribution International License (CC BY 4.0).

http://creativecommons.org/licenses/by/4.0/

\begin{abstract}
In the education field, there are different theories that apply to teaching in general and specific ones targeting mode of teaching English grammar as a foreign language. This study involves neurological evidence through using animation videos which promotes the idea that learning and teaching in an enjoyable environment are much more conducive, than learning in an unpleasant environment. Using animated videos presentations in teaching students English grammar by explaining the English grammar rules, the used videos required too much attention in learning specific words such as "use of conjunctions" and "verbs" in a humorous and economical way. The study targeted 9 students of the fourth grade at an EFL environment and the sample included only a public school of different achieving levels. Finally, the results of the analysis indicate that this technique helped students of fourth graders to memorize the rules in an easier way. The students also felt happy of seeing animation videos as a way of learning English grammar which suggests that students indeed retain much more when learning through animated videos than when learning in a traditional manner (through drills, grammar exercises from a workbook). The study findings support that the educational pedagogy is applicable to language theory as well. It promotes the idea that students of younger ages should be provided with the opportunities to engage in animated videos in order to enhance the learning process.
\end{abstract}

\section{Keywords}

Grammar Skills, English Grammar, Communication, Animations' Videos, Neurology 


\section{Introduction}

Teaching is a gratifying profession, where it is considered to be one of the difficult parts of the teaching process. Teachers are responsible of choosing the right method of teaching according to the students' age to get them engaged in an appropriate lesson (Birbaumer \& Schmidt, 2006). In addition, learning and teaching should both be carried out in a fun manner and this study comes to investigate the animated videos in the teaching process. Teachers and students can benefit from incorporating fun and animation's videos into the classroom and to all types of students (Birbaumer \& Schmidt, 2006: p. 567).

Students must be afforded with the opportunities to learn through the use of what they prefer to see in a classroom environment. Scholars may also question the fact that animations are useful for students in the learning process that it stills worth investigating and incorporated into classrooms when necessary. Teachers should be aware of students' creativeness and inventiveness and they have to incorporate these characteristics into EFL teaching pedagogies. The language barrier must be taken into account by teachers that it is not an easy task to bare (Bani Abdo \& Breen, 2010).

Language games and videos are especially beneficial to foreign language teachers and students. They are more effective than using traditional methods (drills, textbook grammar exercises) in teaching a foreign language. The fun way of teaching pedagogy lowers the student's affective filter and helps students of acquiring EFL.

\section{Statement of Problem}

The researchers discuss one of the most common difficulties that foreign students have of learning English past tense at public schools. Drills and exercises are traditional way of teaching and they may not consider appropriate way of teaching EFL for young students. Adding, mechanical test questions may not assess students' ability to use it in authentic ways. Providing an authentic assessment of students' grammar proficiency, must reflect real-life uses of grammar in context. To develop authentic assessment activities, teachers must have in minds way of teaching English grammar and what types of tasks must give for their students.

\section{Purpose of the Study}

This study investigates the use of animation videos of teaching English grammar where it considered being fun way of teaching strategies. As visual learning is the most appropriate approach of learning. Therefore, using videos are useful and funny way in teaching and not easy to forget. This strategy is used to build a better understanding the manner in which language videos enhance the learning experience of EFL. This technique is trying to get into the neurological aspect of how students learn and retain English grammar. 


\section{Research Questions}

This study will investigate whether teaching grammar through animation videos is beneficial in teaching EFL and how animation would be beneficial for students in learning grammar through emotional levels.

\section{Significance of the Study}

This study is to build a better understanding of how students capture content in a fun process and how this strategy is used to build a better understanding the manner in which language videos enhance the learning experience of EFL. This teaching tool is used to teach grammar of primary school students. In addition, this study this technique is used to build a better understanding of the manner in which language videos enhance the learning experience of EFL. Finally, this technique is trying to get into the neurological aspect of how students learn and retain English grammar.

\section{Review of Literature}

Using animations to teach English grammar for EFL students considers as one of those strategies which is known as "declarative memory". It is responsible for conscious recall of facts and events declarative knowledge (Birbaumer \& Schmidt, 2006: p. 567). This theoretical part leads to a better application of practice. This method is eventually becomes automatic and the declarative knowledge then becomes procedural knowledge. This declarative way of teaching how to formulate rules for morphological and syntactic structures are first taught and then applied. As a foreign language students are required to produce spoken language (from the morphological and syntactical rules, plus vocabulary). Therefore, students are required to proceduralise declarative knowledge in order to be successful in learning the new language. The videos used in this study are helpful in achieving this goal. "Language games are not to be employed in teaching as play in a conventional sense, to provide entertainment: they are employed in a targeted way in order to proceduralise foreign language" (Macedonia, 2005: p. 139; Anthony, 1939; Gahringer, 1959; Molina, 1971; Schrade, 1994; Cherry, 1975). This is to say that using animated videos towards achieving the EFL goals where participants (learners) must learn some grammatical aspect in order to transfer declarative knowledge into a procedural knowledge.

Language learning involves the brain and emotions of learners. The reason for this is "that we are programmed to scan our environment continuously for danger and to adapt our behaviour. Thus, we also assess any learning experience emotionally" (Macedonia, 2005: p. 139).

Therefore, the learning process goes through an emotional level and then associates these emotions with other experiences. For example, if a student is taught grammar by having to practice drills and complete fill-in-the-blank worksheets on a daily basis, it is very likely that the student will associate this unpleasant learning visual experience onto future grammar learning experiences; thus causing the student not to want to engage in this type of learning in the future. 
Then, learning grammar is an important part of teaching and learning of languages. It is one of the difficult and boring sides of languages. Having formal conversation, presentation, or piece of writing requires good commands of English grammar which most students of EFL lack. Teaching grammar rules and applications requires much efforts and time by teachers and instructors. Then, as a result out instructor here uses animations for fun environment of teaching. Though that traditional way of teaching required EFL teachers to explain the forms and rules for students, and then have students to produce correct forms on exercises and tests but using this approach consistently creates students' errors when they try to use the language in context.

Teachers sometimes tend not to teach grammar where they believe that kids acquire their first language without grammar instructions and they consider learning a second language of the same way (Skinner, 1972; Slater, 2004; Smith \& Woodward, 1996). Whereas, grammar instruction carries out students instruction to a correct communication purposes by emotional level of teaching through experiences as Macedonia (2005) believes.

\section{Method}

This quantitative and qualitative analysis investigates teaching English simple grammar drills through an experimental strategy of teaching 9 students of fourth graders at the Great Arab Revolt primary school. This study is comparing the learning and retaining process of acquiring simple English Grammar with or without animated videos. This experiment goes into two parts. The first part of this experiment is to teach these simple grammar drills through the traditional way of teaching where the teacher uses only a piece of white chalk and chalkboard clipart black and white. This technique has no sign of using technology at the classroom (Learn and Retain English Grammar without Animated Videos). The second part of this experiment includes the same control group of students and how these simple grammar drills are learned and retained after showing them related animated videos. These drills contain different tasks (such as, simple past tense, articles, determiners, pronouns, use of 'has' and 'have' etc.) through using animation where their visual and emotional levels of learning lead EFL students to a better understanding of how language works. This strategy then, uses a total of 13 different animations' videos provided in Appendix 1 to teach different grammar drills. These videos are available online. The sample of the study comprises 9 students of a primary public school in Aqaba-Jordan. They are randomly chosen of the fourth graders participants at a Jordanian public school at Aqaba for the fall semester of the academic year 2016/2017. All the students selected for the study are monolingual students (Arabic native speakers) and learn English as a foreign language. They are of different gender 5 males and 4 females and share the same ethnicity, similar age of 10 years old, and the same Arabic Jordanian backgrounds. The instructor divided the student into three groups depending on the achievements (strong students, average student, and low-achieving students). The random sampling "is the best way to obtain a 
representative sample" (Gay \& Airasian, 2003: p. 183). Subsequently, a pre- and post-tests are conducted through the English teacher at the school by the fall academic semester of 2016/2017. Both tests are collected and assigned a grade for each student depending on the Macedonia (2005), where he believes that the learning process goes through an emotional level and then associates these emotions with other experiences. Pre-test and post-test were designed to prove that indoctrination is a deteriorating old method, while the videos used in this study is more enticing to the internet and media driven new generations of students. The changes that occurred on students capturing, understanding, and memorizing the new verbs are recorded and analysed to determine the usefulness of such a method in teaching EFL grammar.

\section{Findings and Discussions}

This section provides a conclusion on the findings of this study which explores teaching grammar through using animations by the 9 students of fourth grade from a Jordanian public school at Aqaba. The study found out that EFL students were able to use different types of grammatical issues such as (determiners, different types of pronouns, questioning techniques, use of have and has, verb to be, and articles).

The Pre-test presented in Table 1 indicates that high-achievements students recorded a medium grade in terms of Nervousness and Shyness, and the Grammatical Mistakes aspects; whereas, they recorder a low grade for these functions in the post-test as Table 2 shows. Two (2) students recorded mid grade and 1 high for Using enough vocabulary, whereas, for the post-test (Table 2) the 3 of them recorded a high grade of using the enough vocabulary. As it for the non-verbal communications, the pre-test (Table 1) scored 2 students high and one low, while the post-test (Table 2) indicates that high and average-students scored low use of the non-verbal communications.

The average-achievements students scored the high-Grade in their pres-test (Table 1) for the Nervousness and Shyness and Using L1 rather than L2 respectively; and mid-grade for both of grammatical mistakes and using enough vocabulary 2 mid 1 high for non-verbal communication. As for the post-test (Table 2) those students, those students, mid-grade for both of Nervousness and Shyness and Using L1 rather than L2. For the non-verbal communications all students scored mid-grade. For Grammatical Mistakes 2 scored low and 1 mid and 2 scored high $1 \mathrm{mid}$ for the Using enough vocabulary function.

The low-achieving students as Table 1 shows scored a high-grade of using Nervousness and Shyness, Grammatical Mistakes, non-verbal communications, and Using L1 rather than L2 respectively. As for the Using enough vocabulary, they all scored a low-grade. On the other hand in Table 2, the post-test shows that the low achieving students scored mid-grade of all functions.

The pre- and post-tests (Table 1 and Table 2) reveal that teaching grammar through using animations is affective. Students have scored better grades in terms of their observed behavior such as (Nervousness and Shyness, Grammatical 
Table 1. Pre-Test: Conducting a regular class with different drills using the tradition way of teaching (without animated videos).

\begin{tabular}{|c|c|c|c|c|c|c|c|c|c|c|c|c|c|c|c|c|}
\hline \multirow{2}{*}{\multicolumn{2}{|c|}{$\begin{array}{c}\text { Observed behaviors } \\
\text { Frequency of observed behaviors }\end{array}$}} & \multicolumn{3}{|c|}{$\begin{array}{c}\text { Nervousness and } \\
\text { Shyness }\end{array}$} & \multicolumn{3}{|c|}{$\begin{array}{l}\text { Grammatical } \\
\text { Mistakes }\end{array}$} & \multicolumn{3}{|c|}{$\begin{array}{c}\text { non-verbal } \\
\text { communications }\end{array}$} & \multicolumn{3}{|c|}{$\begin{array}{l}\text { Using } \mathrm{L} 1 \\
\text { rather than } \mathrm{L} 2\end{array}$} & \multicolumn{3}{|c|}{$\begin{array}{l}\text { Using enough } \\
\text { vocabulary }\end{array}$} \\
\hline & & .00 & $\bar{\Xi}$ & 艿 & 离 & $\Sigma$ & 艿 & 㿣 & $\Sigma$ & 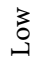 & 票 & $\Sigma$ & $\begin{array}{l}3 \\
0 \\
0 \\
3\end{array}$ & 矛 & $\Sigma$ & 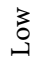 \\
\hline \multirow{3}{*}{ 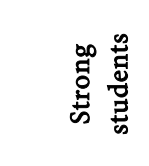 } & S1 & & * & & & * & & & & * & * & & & * & & \\
\hline & S2 & & * & & & * & & & * & & * & & & & * & \\
\hline & S3 & & * & & & * & & & * & & * & & & & * & \\
\hline \multirow{3}{*}{ 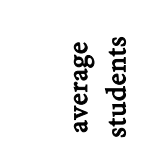 } & S4 & * & & & & * & & & * & & * & & & & * & \\
\hline & S5 & * & & & & * & & * & & & * & & & & * & \\
\hline & S6 & * & & & & * & & & * & & * & & & & * & \\
\hline \multirow{3}{*}{ 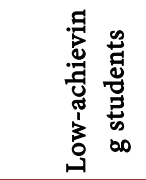 } & S7 & * & & & * & & & * & & & * & & & & & * \\
\hline & S8 & * & & & * & & & * & & & * & & & & & * \\
\hline & S9 & * & & & * & & & * & & & * & & & & & * \\
\hline
\end{tabular}

Table 2. Post-Test: Conducting a regular class with different drills after showing the animated videos.

\begin{tabular}{|c|c|c|c|c|c|c|c|c|c|c|c|c|c|c|c|c|}
\hline \multirow{2}{*}{\multicolumn{2}{|c|}{$\begin{array}{c}\text { Observed behaviors } \\
\text { Frequency of observed behaviors }\end{array}$}} & \multicolumn{3}{|c|}{$\begin{array}{c}\text { Nervousness and } \\
\text { Shyness }\end{array}$} & \multicolumn{3}{|c|}{$\begin{array}{l}\text { Grammatical } \\
\text { Mistakes }\end{array}$} & \multicolumn{3}{|c|}{$\begin{array}{c}\text { non-verbal } \\
\text { communications }\end{array}$} & \multicolumn{3}{|c|}{$\begin{array}{l}\text { Using L1 } \\
\text { rather than L2 }\end{array}$} & \multicolumn{3}{|c|}{$\begin{array}{l}\text { Using enough } \\
\text { vocabulary }\end{array}$} \\
\hline & & 点 & $\Sigma$ & 艿 & 点 & $\Sigma$ & كِ. & 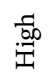 & $\Sigma$ & 艿 & 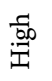 & $\Sigma$ & 艿 & 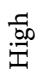 & $\Sigma$ & בְּ \\
\hline \multirow{3}{*}{ 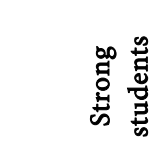 } & S1 & & & * & & & * & & & * & & * & & * & & \\
\hline & S2 & & & * & & & * & & & * & & * & & * & & \\
\hline & S3 & & & * & & & $*$ & & & * & & * & & * & & \\
\hline \multirow{3}{*}{ 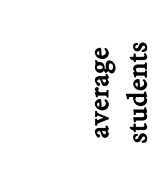 } & S4 & & * & & & & * & & & * & & * & & * & & \\
\hline & S5 & & * & & & * & & & & * & & * & & * & & \\
\hline & S6 & & * & & & & * & & & * & & * & & * & & \\
\hline \multirow{3}{*}{ 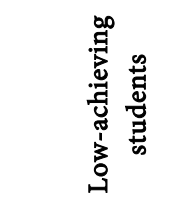 } & S7 & & * & & & * & & & * & & & * & & & * & \\
\hline & S8 & & * & & & * & & & * & & & * & & & * & \\
\hline & S9 & & * & & & * & & & * & & & * & & & * & \\
\hline
\end{tabular}

Mistakes, non-verbal communications, Using L1 (Arabic) rather than L2 (English), and Using enough vocabulary).

The study found out that EFL students were able to use different types of grammatical issues such as (determiners, different types of pronouns, questioning techniques, use of have and has, verb to be, and articles).

Animations focus on teaching students by using different instructions of grammar in the context such as using different animated situation that actually enhances the learning process of students. The videos were beneficial tool for the students and it helps teachers towards achieving their goals. They considered being effective ways to improve English language for students. This teaching technique of using animation also consist of different analysis and report different 
information, because they uses pictures and sounds to present ideas. At the same time they improve student's imagination, skill level, and personal interests. The study also aimed to find out whether there are significant differences in teachers' perceptions of difficulties in relation to their students' gender, qualification, and learning abilities; thus providing insights into their students' difficulties of learning perceptions.

As states that, the role of grammar instruction in an EFL context has been for decades a major issue for students and teachers where researchers debated that classroom traditional way of teaching drills are not successful especially for young students who find grammar is tough to learn while using animations were successful for our study samples. Both genders were equally interested in learning the grammar drill through the fun way of using animations. Teaching with animations can deepen student learning by supporting instructional objectives. However, it can be challenging to select the "best" tech tools while not losing sight of your goals for student learning. Once identified, integrating those tools can itself be a challenge albeit an eye-opening experience. As a result, the pre test indicates that students' sense of identity has been much lower and they have little confidence, therefore, they lack enthusiasm and sense of achievement. Adding the large number of students in a class adjust teachers fail to supervise all of them; whereas, showing a video in the class was more facilitating for teacher to supervise and grabs all students attentions.

According to Macedonia (2005), the study findings revealed that the learning process goes through an emotional level and then associates these emotions with other experiences. Using animation reveals that instructions through them is a deteriorating the old method of teaching. It also shows that the used of animations in this study is tempting and the positive changes occurred for the different levels of students is reflecting the way that those students capturing, understanding, and memorizing the new verbs and pronouns effectively through the use of the videos.

These results may be limited because of the random small sample size of the same background and ethnicity. It might be better to expand the sample in the future studies. This study highlights the nature the different styles that may benefit the students of learning English grammar and might be better to use this strategy of teaching other English language skills. Using 13 Animations videos may also affect the results. According to the emotional level and learning process of Macedonia (2005), the future studies may discuss the emotional status of each participant of the sample.

\section{Conclusion}

To conclude, animations were of useful ways to enhance teaching English grammar for young EFL student. This study reveals that the students' sample had an immense impact on their achievements through using animations to learn some aspects of English grammar. Both tests reveal that these students (9) and instructors (two instructors at the English department) save time and teachers 
were able to supervise all students equally. The results also show that students become more confident and do fewer mistakes in grammar. Students' understanding and the way they perceive the lesson are more efficient than the tradition way where their emotions were driven by the animated videos themselves. This study concludes that the use of animations in the classroom affects the overall achievement of the students through triggering their emotions.

\section{References}

Anthony, A. E. (1939). The Use of Games in the Modern Language Class and Club. The French Review, 13, 14-25.

Bani Abdo, I., \& Breen, G. (2010). Teaching EFL to Jordanian Students: New Strategies for Enhancing English Acquisition in a Distinct Middle Eastern Student Population. Creative Education, 1, 39-50. https://doi.org/10.4236/ce.2010.11007

Birbaumer, N., \& Schmidt, R. F. (2006). Biologische Psychologie (7th ed.). German Edition, Springer.

Cherry, C. (1975). Games and Language. Mind, 84, 528-547. https://doi.org/10.1093/mind/LXXXIV.1.528

Gahringer, R. E. (1959). Can Games Explain Language. The Journal of Philosophy, 56. 661-667. https://doi.org/10.2307/2022121

Gay, L. R., \& Airasian, P. (2003). Educational Research: Competencies for Analysis and Application (7th ed.). NJ: Pearson Education.

Macedonia, M. (2005). Games and Foreign Language Teaching. Support for Learning, 20, 135-140. https://doi.org/10.1111/j.0268-2141.2005.00377.x

Molina, H. (1971). Language Games and the Mexican-American Child Learning English. TESOL Quarterly, 5, 145-148. https://doi.org/10.2307/3585997

Schrade, A. (1994). Gamesplay in Spanish Teaching. Hispania, 77, 519-523.

https://doi.org/10.2307/344987

Skinner, B. F. (1972). Beyond Freedom and Dignity. New York: Vintage Books.

Slater, L. (2004). Opening Skinner's Box: Great Psychological Experiments of the Twentieth Century. New York: W. W. Norton \& Company.

Smith, L. D., \& Woodward, W. R. (1996). B.F Skinner and Behaviorism in American Culture. Bethlehhem, PA: Lehigh University Press. 


\section{Appendix 1: Animation's Videos}

- (https://www.youtube.com/watch?v=g2PaWHJhWpU) ESL : Determiners

- (https://www.youtube.com/watch?v=dJL5gC0oN2M) This, That, These, Thos

- (https://www.youtube.com/watch?v=_mC9BmlMFzk) This That / What is This? What is That? | Grammar Grade 1 | Periwinkle

- (https://www.youtube.com/watch?v=nKk5B8ilyEo) This, These, That, Those, Demonstrative Pronouns Lesson, English for Children

- (https://www.youtube.com/watch?v=NJ4SCxg6i0E) Use of this and that

- (https://www.youtube.com/watch?v=4gQTS1HFT7g) Demonstrative Pronouns, Singular, This, That, English for Children

- (https://www.youtube.com/watch?v=1a9ZrvhzJiw) this, that, these, those

- (https://www.youtube.com/watch?v=foxPINDz7Ao) Using This-TheseThat-Those | Grammar Grade 1 | Periwinkle

- (https://www.youtube.com/watch?v=zJASHLh7VIA) Understanding The Use of "HAS" and "HAVE" for Kids | Grammar Grade 1|Periwinkle

- (https://www.youtube.com/watch?v=DTxMD3r-dLA) Use of AM, IS, ARE with Pronouns | Grammar Grade 1 | Periwinkle

- (https://www.youtube.com/watch?v=mSRpXo7hNY8) Articles A and An for Kids | Grammar Grade 1 | Periwinkle

- (https://www.youtube.com/watch?v=SWnc1HSCvRY) Personal Pronouns for Kids!

- (https://www.youtube.com/watch?v=QUbF913jehw) I, You, He, She, It-English Grammar for Kids

Submit or recommend next manuscript to SCIRP and we will provide best service for you:

Accepting pre-submission inquiries through Email, Facebook, LinkedIn, Twitter, etc.

A wide selection of journals (inclusive of 9 subjects, more than 200 journals)

Providing 24-hour high-quality service

User-friendly online submission system

Fair and swift peer-review system

Efficient typesetting and proofreading procedure

Display of the result of downloads and visits, as well as the number of cited articles

Maximum dissemination of your research work

Submit your manuscript at: http://papersubmission.scirp.org/

Or contact ce@scirp.org 